Agroforestry Systems 20: 117-139, 1992.

(C) 1992 Kluwer Academic Publishers. Printed in the Netherlands

\title{
Trees and shrubs as sources of fodder in Australia
}

\author{
E.C. LEFROY ${ }^{1}$, P. R. DANN ${ }^{2}$, J. H. WILDIN ${ }^{3}$, R.N. WESLEY-SMITH ${ }^{4}$ \\ and A. A. McGOWAN ${ }^{5}$ \\ ${ }^{1}$ Western Australian Department of Agriculture, Perth; ${ }^{2}$ CSIRO, Canberra; ${ }^{3}$ Department of \\ Primary Industries, Rockhampton, Queensland; ${ }^{4}$ Department of Primary Industries and \\ Fisheries, Berrimah, Northern Territory; ${ }^{5}$ Victorian Department of Agriculture, Ellinbank
}

Key words: browse, Leucaena, Chamaecytisus, Atriplex, acacia

\begin{abstract}
Experience with browse plants in Australia is briefly reviewed in terms of their forage value to animals, their economic value to the landholder and their ecological contribution to landscape stability. Of the cultivated species only two have achieved any degree of commercial acceptance (Leucaena leucocephala and Chamaecytisus palmensis). Both of these are of sufficiently high forage value to be used as the sole source of feed during seasonal periods of nutritional shortage. Both are also leguminous shrubs that establish readily from seed. It is suggested that a limitation in their present use is the reliance on stands of single species which leaves these grazing systems vulnerable to disease and insects. Grazing systems so far developed for high production and persistence of cultivated species involve short periods of intense grazing followed by long periods of recovery. Similar management may be necessary in the arid and semi-arid rangelands where palatable browse species are in decline.
\end{abstract}

\section{Introduction}

Trees and shrubs, often called browse or topfeed, have long been considered important for the nutrition of grazing animals in Australia, particularly in those areas with a pronounced dry season $[3,14]$. They provide a supplement of green feed when grasses and other herbaceous material is dry and they provide the only source of protein and energy during drought when all other feed is absent.

At the same time trees and shrubs have several disadvantages as sources of feed. They are often inaccessible to grazing animals. They are slow to establish requiring isolation from stock. Their foliage generally has higher fibre and lignin content than grasses [52], and often has higher levels of tannins and other astringent compounds than shorter lived herbaceous plants. Although sometimes higher in protein, they often have lower energy value than herbaceous plants due to their lower digestibility.

As a consequence of these factors they are rarely the first choice of grazing animals and seldom make up a significant proportion of the diet when grass and other herbaceous feed is available $[12,19,42]$.

To assess the contribution of browse species to grazing systems it is necessary to consider in turn their forage value to the animals, their economic value to the landholder and their ecological value in the landscape. 


\section{Assessing the value of browse plants}

Increasing interest in the integration of trees and shrubs into broadacre agriculture is due in part to greater awareness of their protective role. This is particularly so in areas where agriculture has disrupted processes important in landscape stability such as the cycling of water and nutrients.

In the case of browse plants, their productive value needs to be carefully assessed before it can be considered as an incentive to their wider use in a protective role.

This productive role has two aspects; nutritional and economic. While a particular browse plant may be capable of maintaining or even fattening animals when handfed in an experiment, the cost of establishment and management in comparison to alternative feeds may not justify its wider use.

The place of cultivated browse plants is often limited by two factors. The marked seasonal nature of their feed advantage and the higher costs involved in growing and managing trees and shrubs compared to other forage plants. Together these limit the period of the year in which they have an economic advantage over other feed sources. In many cases this will restrict the area that can be profitably established to browse plants to that area sufficient to supply feed during a two to three month period each year, or about 10 to $20 \%$ of farm size. To plant a larger area requires a livestock trading enterprise that can take full advantage of an out-of-season feed supply.

Whichever case, the value of trees and shrubs as fodder needs to be kept in perspective with other commercial end uses when examining incentives for planting trees on farms.

\subsection{Forage value}

The forage value of any feed depends on the combination of its palatability, nutritive value and digestibility. These need to be sufficiently high for an animal to take in its daily requirement of energy, protein and minerals. That minimum requirement varies with the type of animal, the desired result (maintenance, weight gain, wool growth, milk production) and climatic conditions. For a $50 \mathrm{~kg}$ wether for example, the daily maintenance requirement is eight megajoules of metabolizable energy, $95 \mathrm{~g}$ of crude protein, $5 \mathrm{~g}$ of calcium, $1 \mathrm{~g}$ of magnesium and $2 \mathrm{~g}$ of sodium [39]. To acquire this amount of energy means taking in $500 \mathrm{~g}$ of digestible organic matter, or $1.1 \mathrm{~kg}$ dry weight of feed that is $55 \%$ digestible.

The intake of sufficient energy and nutrients by an animal cannot be predicted from separate analysis of a plant's nutrient content, digestibility or palatability. Despite this, the wider use of trees and shrubs as forage is often advocated on the basis of such analyses $[3,4,14,45]$. While these can serve as some guide to the value of species, they must be regarded with caution for several reasons. 
Firstly, chemical analysis commonly overestimates digestibility, particularly that of protein, as it does not take into account the fact that protein is often bound to lignin and tannins which can prevent its breakdown in animals $[6,27]$. Secondly, digestibility can be a poor indicator of forage value as shown in a study of seven common Australian browse plants where there was no relationship between true digestibility and the amount voluntarily eaten by sheep [53]. Thirdly, palatability can vary seasonally and between animals and cannot therefore be assessed on the basis of the occasional consumption of browse $[6,52]$.

Even when pen feeding experiments are carried out, the results can be misleading with browse plants. In such experiments, the material is collected by hand so the results are insensitive to the accessibility of the feed. Accessibility is not only a function of height, but also of the spatial distribution or density of the edible material, and therefore the amount of foraging required by the animal to take in sufficient feed.

For these reasons, an accurate assessment of the forage value of browse species can only be made from the response of grazing animals. This paper concentrates on species for which such information is available. A summary of the factors important in assessing forage value is given in Table 1.

Table 1. Assessing the value of browse plants.
I. Forage value to the animal
II. Economic value to the landholder
III. Landscape value to the farm or catchment

Is the plant material:
- accessible
- acceptable
- digestible $(>55 \% \mathrm{DMD})^{*}$
- sufficiently high in
- energy
- protein
- minerals
- non-toxic

Measure:

response in grazing animals
- establishment cost

- management cost

- time to first use

- substitution value

- persistence

- complementary effects

- competitive effects

Measure:

return on investment
Does the plant match site requirements for:

- reduced wind erosion

- reduced water erosion

- water use

- increased nutrient cycling

- improved soil structure

- increased genetic diversity

- decreased energy inputs

Measure:

landscape stability

* DMD is dry matter digestibility.

\subsection{Economic value}

Assuming that a browse plant can meet the required forage value, its economic value to the landholder will depend on some additional characteristics of the plant; the cost of establishing and managing the trees and shrubs, the time taken for them to reach a productive age, the persistence of the plant 
under regular use (in terms of both its ability to regrow each year and its longevity), the ability of the plant to produce feed when it is most needed.

These attributes can be expressed in terms of its substitution value, meaning the cost of producing browse feed compared to the cost of alternative feed sources necessary to achieve the same animal response. By taking into account the expected life of the plants, this value can also be expressed as the rate of return on investment.

Assessment of economic value also needs to take into account any complementary or competitive effects of trees and shrubs. An example of a complementary effect is deferred grazing; by having browse feed available during a time of seasonal shortage, other areas of land can be relieved of grazing pressure and given an opportunity to consolidate. Another complementary effect is the increased growth of herbaceous species growing amongst browse plants due to shelter or shade effects [15, 44].

Competitive effects include the lost production from herbaceous plants on the land occupied by the browse species. A summary of the factors important in economic assessment is shown in Table 1.

\subsection{Landscape values}

Like all trees and shrubs, browse species can make a valuable contribution to landscape stability by decreasing the risk of wind and water erosion. They also contribute to the cycling of nutrients, especially nitrogen in the case of legumes, and the cycling of water.

Their deeper and more permanent root systems also help to overcome problems of declining surface structure and compaction commonly associated with crop and pasture land. The introduction of browse plants can also increase the genetic diversity in the landscape and therefore help to increase the resilience of the vegetative cover in general to pests, diseases, fire and climatic extremes.

The use of perennial plants can also increase the energy efficiency of agriculture by reducing the requirement for cultivation, and in the case of legumes, reduced input of fertilizer.

Browse plants are becoming important in parts of Australia because they bring these attributes to land that is unproductive under conventional agriculture or is degraded due to erosion or salinity. A summary of these landscape values is given in Table 1 .

\subsection{Distribution of species by climatic zones}

Figure 1 shows Australia divided into the major climatic zones. Browse plants have some role in grazing industries in all of these zones. Indigenous species are most important in the semi-arid and arid zones while cultivated species are being used in the monsoonal, subtropical and temperate zones. 


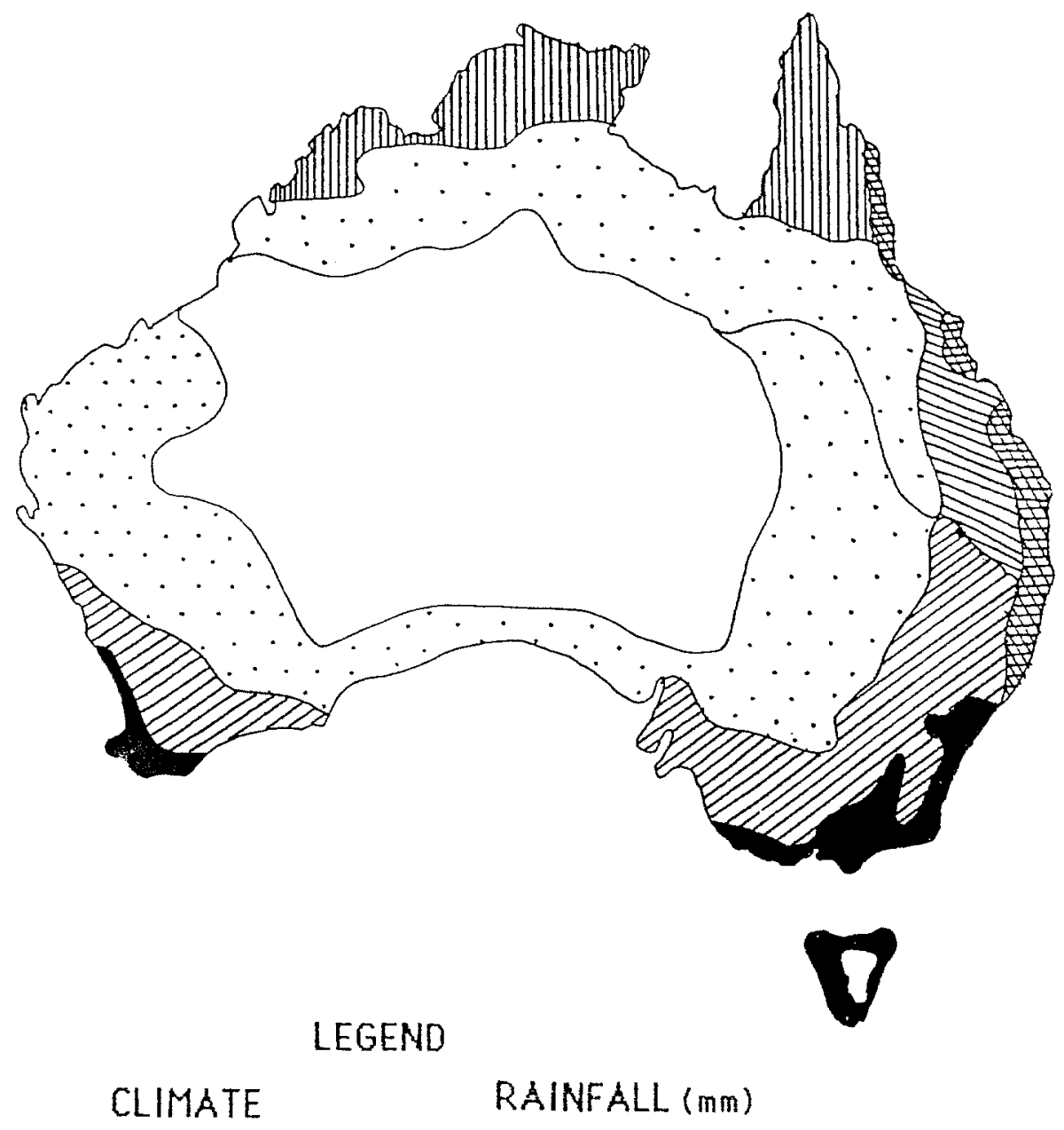

1. Wet temperate

2.Dry temperate

3.Semi-arid (south)

4.Arid

5.Semi-arid (north)

6.Dry sub-tropics

7.Het sub-tropics

8.Monsoonal

$>600$
$300-600$
$200-400$
$>200$
$300-700$
$600-1200$
$>1000$
$>700$

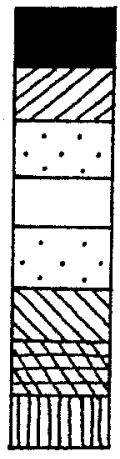

Fig. 1. The major climatic zones of Australia. 


\section{Arid and semi-arid rangelands}

\subsection{The role of browse plants in the rangelands}

Over $70 \%$ of Australia falls within the arid and semi-arid climatic zones. The dominant land use is extensive grazing by sheep and cattle at stocking rates that vary from the equivalent of 1 sheep to 4 ha to 1 sheep to 40 ha. This wide range in carrying capacity reflects variation in vegetation type and it is within three main vegetation types that edible trees and shrubs are found. These are the Acacia shrublands occurring mainly in the south and centre, the low Chenopod shrublands of the south and the semi-arid woodland to the east and north. The remaining important vegetation type of this region is grassland.

The first two of these vegetation types (Acacia and Chenopod shrubland) occupy $26 \%$ and $5 \%$ of the Australian land mass, respectively [43]. Table 2 lists some of the browse plants of this region.

Despite historical reference to their general value to the grazing industry $[3,9,14]$ it is apparent from more recent studies that their contribution to animal production in most seasons is very small as both sheep and cattle heavily favour annual and perennial grasses and forbs due to their consistently higher digestibility. In particular, little or no relationship has been shown between a high density of browse plants and high animal productivity in the riverine plain of eastern Australia $[11,12,19]$. Similarly a comparison of rangeland with low and high density of palatable shrubs in Western Australia showed no difference in wool production over five years except at very high stocking rates in a drought year. At average to low stocking rates (6 to 12 ha per sheep) there was no difference in wool production as the area with less shrubs produced three to four times the amount of herbaceous feed [47].

In central Australia, studies of the botanical composition of the diet selected by cattle have shown that browse usually comprises less than $10 \%$ of the diet but may rise to $20 \%$ during very dry times [2, 42] (see Fig. 2 ).

In short it is fairly well established that the major value of browse species to the grazing industries in the arid and semi-arid zones is in ensuring continuity of animal production over very dry periods. In addition, studies of land degradation in the rangelands have concluded that shrubs, through their roles in nutrient cycling and erosion prevention, are important in preserving landscape stability $[24,50]$. However, no detailed studies to date have been of long enough duration to demonstrate an economic benefit in this regard.

For these reasons it is of concern that the density of palatable browse species is decreasing in both the Chenopod shrublands and the Acacia shrublands, that grazing pressure plus the exclusion of fire is causing grasses to be displaced by less desirable woody plants in semi-arid woodlands and that levels of erosion are increasing in all three $[48,54]$.

The apparent lack of economic incentive to reverse these trends means 


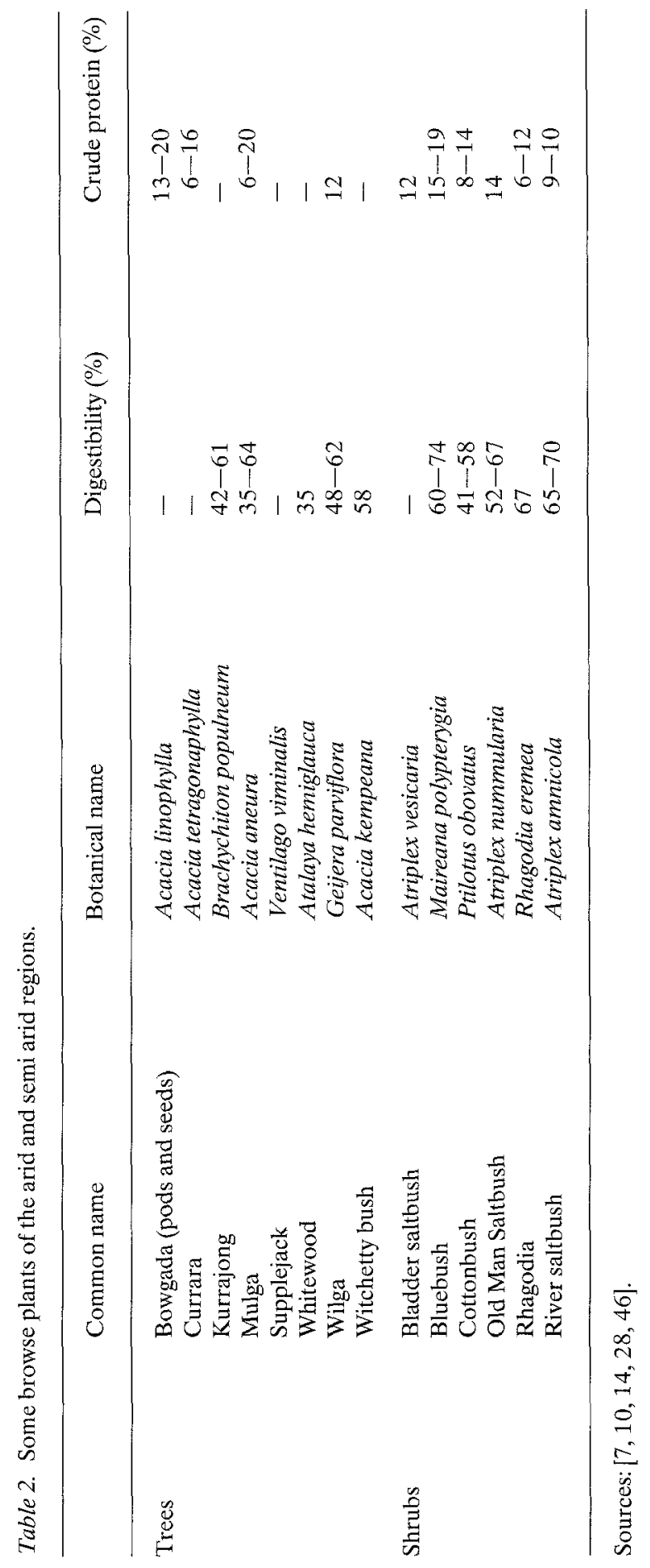




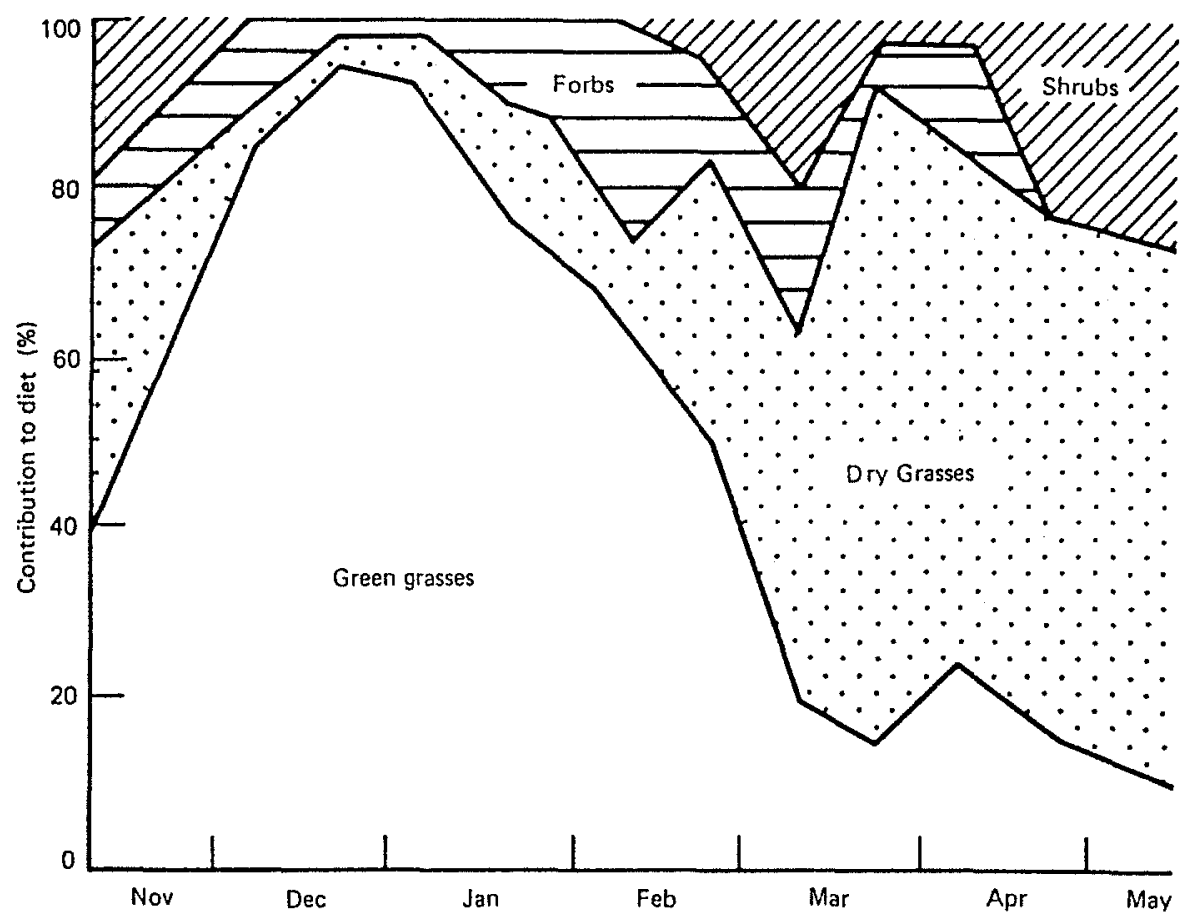

Fig. 2. Proportions of green grass, dry grass, forbs and shrubs in the diet of steers grazing between November 1977 and May 1978, Alice Springs (from Squires and Siebert, 1983 [42]).

that the preservation of range condition is seen to be largely dependent on the development of a conservation ethic among landholders. To this end, monitoring sites are being established throughout Western Australia and South Australia. These are intended to both detail changes in range condition, and through regular photography to have a graphic educational role [13].

\subsection{The future of browse plants in the rangelands}

The retention of desirable species in the rangelands, both in terms of their ecological functions and their value for animal production, will depend on an understanding of the interactions between several factors. Important among these are grazing intensity, grazing frequency, location of watering points, the use of fire, the populations of native and feral animals and local variations in climate and soil type.

While theoretical frameworks put forward by ecologists can be useful in developing management prescriptions [40], the long-term experience and observations of landholders are an invaluable source of information that has 
possibly been under-utilized. This is particularly so because their experience is based on observing the interactions mentioned above at the scale of operations most relevant to other managers; that of an entire pastoral lease and not one paddock or other restricted study area.

Two published examples of such work [29,34] offer examples for future co-operative study into management strategies. In the first case, observations over 28 years have shown that a conservative stocking rate and a rotational grazing system designed to increase recruitment of chenopod shrubs have resulted in an increase in shrub density and patterns of wool production and lambing percentage that are relatively independent of rainfall. A survey of 12 nearby pastoral leases showed this one to have the lowest overall stocking rate (1 sheep to 21 ha compared to 1 to 13 ) and the highest income per hectare. This last point suggests that financial incentives as well as a growing land ethic may contribute to the development of sustainable grazing systems in some areas.

\section{Cultivated species}

The total area of trees and shrubs cultivated for fodder in Australia amounts to between 20,000 and 30,000 ha only. This is divided between the subtropical north-east coast and the dry temperate south-west. Small areas have also been planted in the temperate south-east and under irrigation in the northwestern monsoonal zone.

Over three-quarters of the total area is accounted for by two species; leucaena (Leucaena leucocephala) in the north and tagasaste (Chamaecytisus palmensis) in the south.

Both are multi-branched leguminous shrubs that appear to be vigorous early colonizers of disturbed ground in their respective habitats. Smaller areas of various saltbush (Atriplex spp.), Acacias, poplars (Populus spp.), willows (Salix spp.) and carob (Ceratonia siliqua) have been planted in southern Australia (Table 3). Work is in progress at several institutions throughout Australia to select further species, primarily for the sub-tropics (Table 4).

\subsection{Subtropical north-east}

\section{Leucaena (Leucaena leucocephala)}

Some 16,000 ha of leucaena have been planted in the last 10 years in areas receiving between $500-1000 \mathrm{~mm}$ annual rainfall. The high forage quality of its foliage has been well established [16] as has its ability to produce high liveweight gains in cattle [35].

Its current role in dryland cattle production is to supply high quality feed during the traditional period of nutritional stress from April to October when other pasture is of low quality. In this way cattle are being fattened in areas 


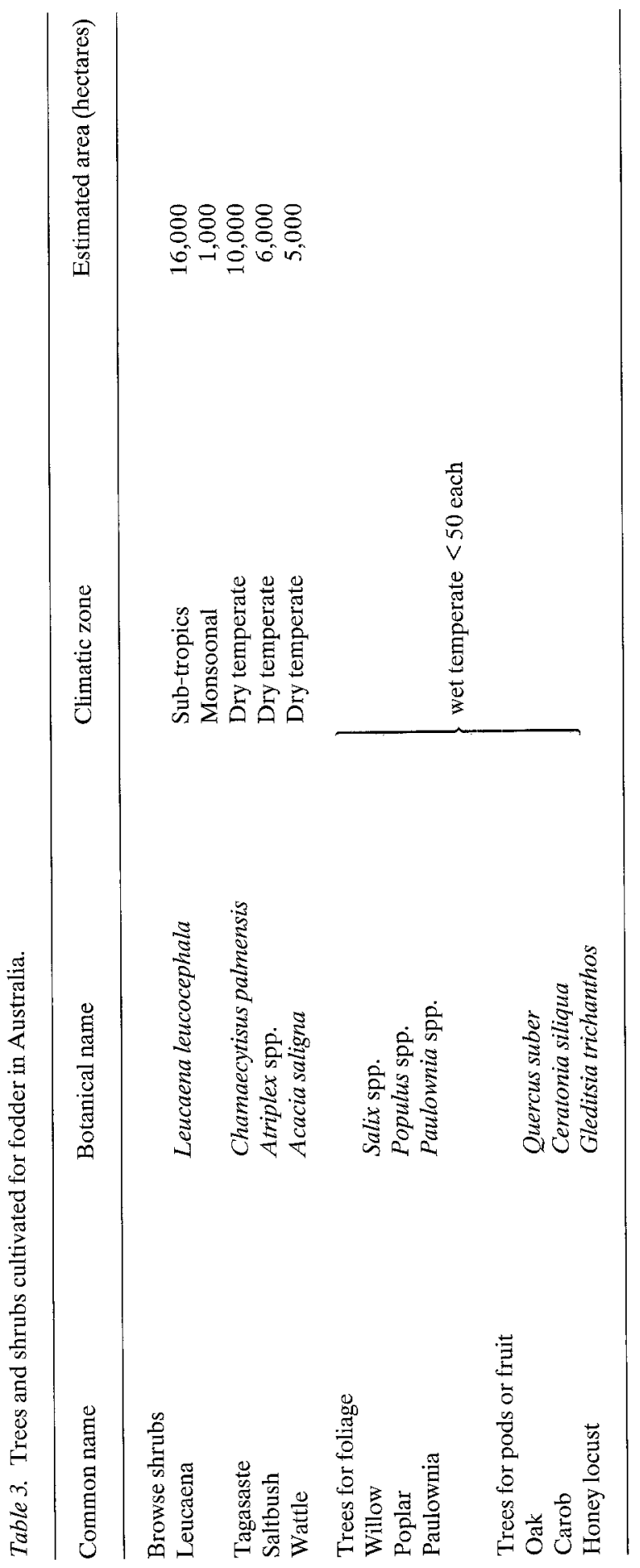


Table 4. Some species of fodder trees and shrubs currently under investigation in Australia.

\begin{tabular}{ll}
\hline Species & Institution* \\
\hline Acacia angustissima & QDPI/CSIRO \\
Acacia aneura & QDPI(Chareville) \\
Acacia microbotrya & WADA \\
Acacia saligna & WADA \\
Albezia chinensis & QDPI/CSIRO; University; of Queensland \\
Albezia lebbeck & QDPI/CSIRO \\
Atriplex amnicola & WADA/DARA \\
Atriplex lentiformis & WADA/DARA \\
Atriplex undulata & WADA/DARA \\
Bitumenaria bitumenosa & WADA \\
Cajanus cajan & QDPI/CSIRO; University of Queensland \\
Callianadra calothyrus & QDPI/CSIRO; University of Queenland \\
Chamaecytisus palmensis & MRP: DARA: NSWAF \\
Cytissus mollis & WADA \\
Gliricidia sepium & QDPI/CSIRO; University of Queensland \\
Leucaena diversifolia & QDPI/CSIRO \\
Leucaena leucocephala & QDPI/CSIRO; University of Queensland; WADA \\
Leucaena pallida & QDPI/CSIRO \\
Medicago arborea & WADA \\
Sesbania sesban & University of Queensland; QDPI \\
Teline monspessulana & WADA
\end{tabular}

QDPI = Queensland Department of Primary Industries.

CSIRO $=$ CSIRO Division of Tropical Crops and Pastures.

WADA $=$ Western Australian Department of Agriculture.

MRP = Martindale Research Project, University of Western Australia.

DARA $=$ Department of Agriculture and Rural Affairs, Victoria.

NSWAF $=$ New South Wales Department of Agriculture and Fisheries.

previously only suitable for breeding. Liveweight gains of $200-300 \mathrm{~kg} / \mathrm{ha}$ per year have meant gross returns of about $\$ 250 /$ ha from leucaena at current prices. Establishment costs are in the order of $\$ 200-250 /$ ha [51].

Under dryland conditions, establishment is by direct seeding in rows 5 to $10 \mathrm{~m}$ apart with first grazing at 12 months. Grasses such as buffel (Cenchrus ciliaris) and panic (Panicum maximum) are sometimes sown in the inter-row 12 months after establishment. Cutting is unnecessary as grazing alone will keep all regrowth within the reach of cattle. Under irrigation, denser stands sown in rows $2 \mathrm{~m}$ apart have produced liveweight gains of about $1000 \mathrm{~kg} /$ ha/year.

Problems were initially encountered with the side effects of the high mimosine content of leucaena. The breakdown of this amino acid to the toxic compound 3 hydroxy-4-(IH) pyridone (DHP) resulted in hair loss, weight loss and in some cases death which limited the role of leucaena to that of a supplement. A bacteria capable of degrading DHP has since been introduced 


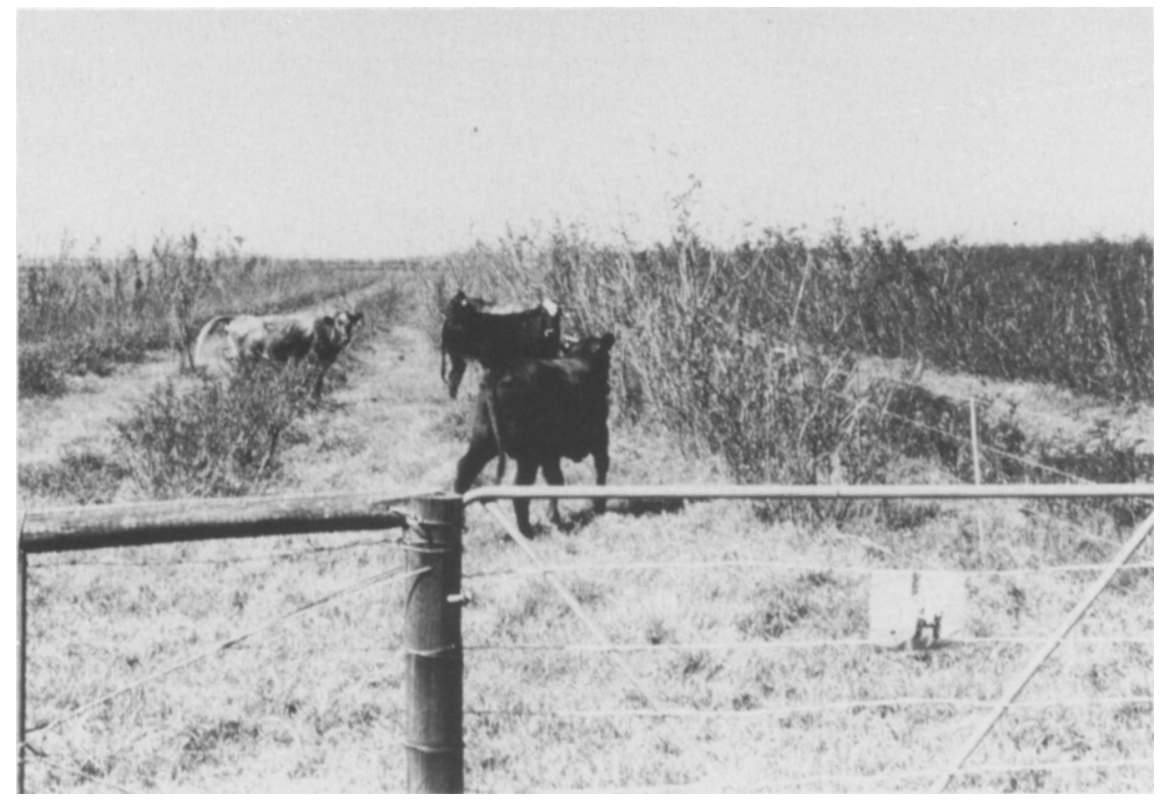

Fig. 3. Cattle grazing irrigated leucaena (Leucaena leucocephala). Photo: D. Pratchett.

to most districts and leucaena now constitutes the sole feed source in many cases.

The arrival of the leucaena psyllid (Heteropsylla cubana) in 1986 was a cause of concern however it now appears that the damage caused by this leaf-sucking insect is restricted to more humid coastal areas.

However, selecting for psyllid resistance is seen as a high priority for research. Other areas seen as requiring work are selection for early growth and hence better establishment, selection for frost resistance to extend its range and selection of other species to limit the risk of heavy dependence on one plant to fill this role.

\subsection{Monsoonal north-west}

About 1000 ha of leucaena is being grown under irrigation on heavy clay soils of the Ord Irrigation Area for fattening cattle [32]. Growth rates of 0.75 $\mathrm{kg} /$ head/day have consistently been achieved at stocking rates of 7.5 animals per hectare (Fig. 3). The current system of grazing involves rotating cattle at an average stocking rate of 7.5 per hectare through paddocks with rows of leucaena planted $3 \mathrm{~m}$ apart. Paddocks are grazed for one week and allowed three weeks to recover before next use.

Range reared cattle are presently being fattened from $150 \mathrm{~kg}$ to 300 or 


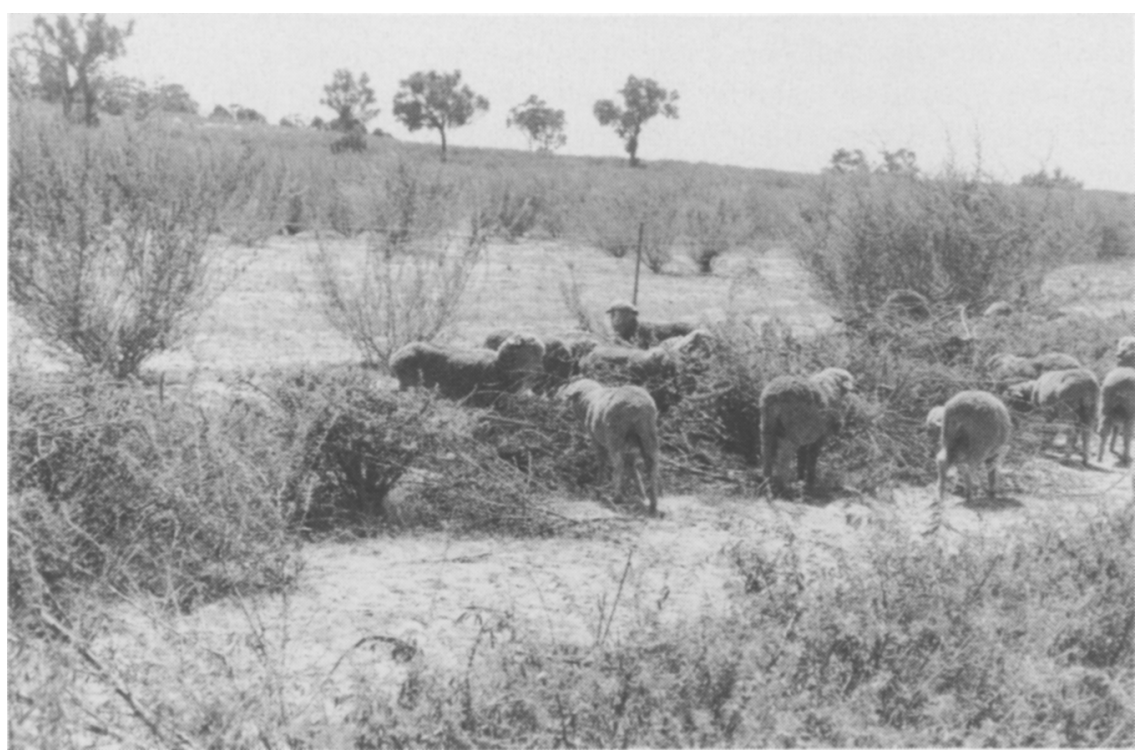

Fig. 4. Young sheep grazing tagasaste (Chamaecytisus palmensis). Photo: C. M. Oldham.

$400 \mathrm{~kg}$ depending on the market. The average gross return per hectare in 1990 was $\$ 1750$ [33]. Land preparation and seeding costs range from $\$ 200$ to $\$ 650 /$ ha.

Establishment is seen as an area for further work with weed competition and low seedling vigour under these conditions the major problem. High stocking rates on irrigated clays means that compaction may cause damage to soil structure and plant roots and be a major limitation of this system. A high priority is to find an inter-row grass that will establish easily from seed.

\subsection{Dry temperate zone}

This winter rainfall zone takes in the cereal and sheep growing area of southern Australia receiving between 250 and $600 \mathrm{~mm}$ of rainfall annually. Cereal crops are grown in rotation with annual pasture or grain legume crops. The temperate zone supports the majority of Australia's 200 million sheep. Many of these are fed supplements of grain for two to three months over autumn and early winter each year. This supplementation fills the gap between the last of the crop residues plus dry annual pasture and the first growth of the next season's pasture.

Three cultivated browse plants are presently being used on a small scale as substitutes for this supplementary feeding; tagasaste (Chamaecytisus pal- 
mensis), saltbush (various species of Atriplex) and acacia (Acacia saligna). There is also interest in these fodder shrubs for their potential ability to increase water use and hence overcome problems of rising water tables and increasing secondary salinity. They also have a role to play in stabilizing areas affected by erosion, in sheltering stock from adverse weather conditions and in providing habitat for beneficial insects and wildlife in general. It is their value as forage however that will act as a primary incentive to their wider use.

\section{Tagasaste (Chamaecytisus palmensis)}

This shrub is native to the arid slopes of the island of La Palma in the Canary Islands and was first introduced to Australia in 1879. It is now naturalised in Southern Australia on freely drained soils in areas receiving more than 500 $\mathrm{mm}$ of annual rainfall. It is intolerant of frost, waterlogging or salinity [38]. Some 10,000 ha were planted on predominantly deep sandy soils on farms in Western Australia between 1985 and 1990 (Fig. 4). Smaller experimental areas have been planted in Victoria, New South Wales and South Australia.

Forage value of tagasaste. This shrub grows vigorously on deep infertile soils yielding 3 tonnes per hectare of edible dry matter each year on $450 \mathrm{~mm}$ of rainfall [7,31], and up to 9 tonnes per hectare on $1100 \mathrm{~mm}$ rainfall [26]. The combination of the shrubs and the inter-row pasture brings production in line with the generally accepted relationship between effective rainfall and forage production in this climatic zone of around one tonne per hectare for every $100 \mathrm{~mm}$ of rain [49].

In summer, the edible fraction (leaf plus stem $<5 \mathrm{~mm}$ ) of tagasaste contains about $15 \%$ protein and is about $70 \%$ digestible. It will regrow rapidly after cutting or grazing in summer without rainfall. As it tends to grow into a spreading shrub up to $5 \mathrm{~m}$ high, it has been found necessary to mechanically prune trees grown under cultivation. Trees are generally grown in rows 5 to $10 \mathrm{~m}$ apart at densities of about 1000 to 2000 trees per hectare and cut once a year prior to grazing.

The current pattern of use involves grazing shrubs once a year over a 3060 day period at high stocking rates (up to 50 sheep per hectare) followed by a 10 month rest period over winter and spring.

With $450 \mathrm{~mm}$ rainfall per year, this regime has produced a yield of about 3000 sheep grazing days per hectare per year. Tagasaste used in this way has maintained sheep in the same or better condition as dry annual pasture plus grain supplement over five years of experiments [31]. With higher rainfall, it is likely that the frequency of grazing or harvesting can be increased.

Growth rates of sheep and cattle on tagasaste are much less than estimates suggested by chemical analysis $[7,26]$ but it is capable of reducing the loss of condition normally experienced in autumn. From a starting weight of $32 \mathrm{~kg}$, young sheep in one experiment lost $2 \mathrm{~kg}$ over a 20 week period on tagasaste 
compared to $5 \mathrm{~kg}$ over the same period on dry pasture and grain supplement [31].

With cattle, liveweight gains have been insignificant when they are forced to eat all the browse available in a paddock. When moved regularly onto fresh paddocks, they have shown liveweight gains of 500 to $600 \mathrm{~g}$ per day. This suggests that sequential use by cattle and sheep may produce liveweight gains in cattle and supply maintenance for sheep.

The ability of tagasaste to grow extra wool compared to dry pasture and supplements has been demonstrated in three consecutive years with young sheep. Clean fleece weights were increased by 25 to $30 \%$; however, the quality and subsequently the value of the extra wool has been inconsistent [31].

Economic value of tagasaste. Tagasaste can profitably substitute for hand feeding of grain as maintenance feed for young sheep with returns on investment of $23 \%$ at a yield of 3400 sheep grazing days per hectare and $10 \%$ at 2170 sheep grazing days per hectare [25]. This analysis was based on the actual establishment, management and yield of a commercial plantation, including the cost of fencing and cutting, and assuming the plantation has a life of 15 years.

It has been shown that the efficiency of utilization of this feed source can be further improved by ration grazing. Sheep have been maintained in similar condition over autumn whether they had access to tagasaste for seven days a week, three days a week and only one day a week, with the three groups showing no significant difference in clean fleece weight or quality [31].

The profitability of using tagasaste to grow extra wool over summer and autumn on tagasaste is less conclusive. Although wool growth rates can be maintained at higher levels than that of flockmates on dry summer pasture, inconsistent effects on mean fibre diameter have meant returns have varied from a loss in one year to an increase in returns of $15 \%$ in other years.

Tagasaste is usually established using specialized tree seeders. These machines rip, scalp a $1 \mathrm{~m}$ width of topsoil to remove weeds and weed seed, drop about 10 seeds per metre of row and follow with a press wheel. The cost varies from $\$ 80$ to $\$ 150$ per hectare. Maintaining shrubs at grazing height requires annual pruning at $\$ 30 /$ ha.

Landscape value of tagasaste. Tagasaste has shown it can fill an important gap in current land use patterns. There are several million hectares of infertile sandy soils in southern Australia. While 600,000 ha of the more fertile of these sandy soils are currently used for the production of grain lupins, much of this area has proved unsatisfactory for annual pasture or cereal growing and remains susceptible to wind erosion and in many cases contributes to recharge of ground water and subsequent valley floor salinity. 
Although it has been shown that tagasaste can be more productive than alternative uses of these soils in a $450 \mathrm{~mm}$ rainfall area, the role it can play is limited by the fact that it only appears profitable to plant up to the point that the autumn feed gap is filled. On most farms this amounts to about $10 \%$ of farm size [31].

Further research may demonstrate it has a profitable role in increasing the year round carrying capacity of sheep or cattle.

Other perennial species are currently being screened for the temperate zone (see Table 4). In this way it is hoped to increase the range of browse plants available to reduce the risk of depending on one species and to select species that do not require pruning. Perennial grasses may also have a role in complementing the feed of browse plants. Preliminary investigations with perennial veldt grass (Erharta calycina var. "Mission") and Rhodes grass (Chloris gayana var. "Pioneer") suggest they can increase the carrying capacity in years with summer rain when sown between rows of tagasaste [C.M. Oldham pers. comm.].

\section{Saltbush (Atriplex sp.)}

Over one million hectares of land have become saline this century in southern Australia as a result of clearing for agriculture. Selection of salt tolerant plants from Australia and overseas for their ability to produce forage on saline land has resulted in about 6000 hectares of shrubs established on farms in the last decade.

Those indigenous to the salt lakes and drainage lines of dry temperate and semi-arid Australia include River Saltbush (Atriplex amnicola), Grey Saltbush ( $A$. cinerea), Old Man Saltbush ( $A$. nummularia) and small leaved bluebush (Maireana brevifolia). Two well adapted exotic species are Quail Brush from southern United States (A. lentiformis) and Wavy Leaved Saltbush from Chile (A. undulata) [21].

Two other indigenous species, Samphire (Halosarcia spp.) and Marsh Saltbush (A. paludosa), often spread naturally in saltland managed for grazing and contribute to the feed supply but are rarely planted [22].

Forage value of saltbush. Commercial experience has shown that saltbush and bluebush pastures can be used to maintain the condition of sheep over summer and autumn as a substitute to grain feeding [22].

There is, however, little experimental work comparing the nutritional value of saltbush with alternative feeds. One study has indicated there are disadvantages with a pure saltbush diet compared to a mixed diet of saltbush and hay. Sheep fed Atriplex undulata, A. lentiformis, $A$. amnicola and $A$. cinerea diets lost weight at about $200 \mathrm{~g}$ per day while sheep on an equal mixture of oaten hay and $A$. undulata gained $70 \mathrm{~g}$ per day over the three week trial [46].

The likely advantages of the mixed diet are a lowered salt intake than the 
pure saltbush diet and higher crude protein than the pure hay. The high salt content of the saltbush diets (150-180 $\mathrm{g}$ total ash per $\mathrm{kg}$ dry matter) may have meant that sheep reached their upper daily limit of salt before there had been sufficient intake for maintenance.

In addition, an average water intake of 8 litres per kilogram dry matter of saltbush may be responsible for lowering the efficiency of digestion [1]. The two species with highest sodium, potassium and total ash content (A. amnicola and $A$. cinerea) had significantly lower nitrogen digestibility in this experiment.

This suggests the role of saltbush is as a supplement of protein and other nutrients normally at low levels in dry grass and crop residues. In that case the establishment of companion grasses in saltland such as Puccinellia ciliata and Agropyron elongatum becomes equally important, as does the grazing of saltland in conjunction with crop residues and dry pasture.

Accessibility limits the forage value under grazing of two species, $A$. nummularia and $A$. lentiformis, both exceeding the $1.2 \mathrm{~m}$ browsing height of sheep. For this reason they are often planted as a small proportion within a mixture of shrubs.

The forage value of saltbush may also be limited by the presence of oxalates which are toxic to ruminants. Levels of about $6 \%$ in $A$. amnicola and $A$. undulata and $9-14 \%$ in Maireana brevifolia have been recorded [46].

Economic value of saltbush. Under commercial practice sheep grazing saltbush pastures select a mixed diet that includes grass and other herbage which would complement the shrub forage and offset the ill effects of a high saltbush diet $[12,19,20]$.

Estimates to date of the profitability of saltbush under cultivation have been based on the assumption that saltbush is the sole source of nutrition and have assumed levels of dry matter intake (and subsequently metabolizable energy) that have not been born out in practice [37].

From commercial practice it is reported that stands of saltbush plus volunteer herbage can provide up to 2500 grazing days per hectare per year and maintain the condition of sheep [22]. In such cases the value of saltbush can be expressed in terms of the cost of alternative feed. Hand feeding of grain currently costs about $\$ 1$ per head per month and would be necessary for two to three months each year. On that basis saltbush pastures yielding 2500 grazing days per hectare per year return between $\$ 28$ and $\$ 42$ per hectare annually.

Saltbush pastures are currently established from seed using niche seeding techniques [23]. Seeds are sown in mounded rows about $3 \mathrm{~m}$ apart with 2 to $3 \mathrm{~m}$ between plants in a row. The cost of establishment is between $\$ 200$ and $\$ 280$ per hectare.

As saltbush and bluebush both recruit from seed or by layering, the 
lifespan of individual plants is not important for the persistence of a pasture where grazing is restricted to two or three months each autumn.

Landscape value of saltbush. Saltbush can stabilize areas of bare saltland, reducing the risk of water and wind erosion and improving both soil structure and nutrient cycling. Saltbush can also prevent further rise in saline watertables [C.V. Malcolm, pers. comm.]. However in some areas, it may be necessary to incorporate deeper rooted salt tolerant trees in order to stabilize watertables.

\section{Acacia (A. saligna)}

Acacia saligna is indigenous to sandplain areas of the temperate zone of Western Australia.

Ironically this shrub is more widely used for forage and soil conservation in the Mediterranean region than in Australia [18, 41]. In the last five years however, some 5000 ha have been directly seeded into a range of soil types from deep sand to mildly saline and waterlogged sandy clays. Some of this is grazed by sheep.

Forage value of acacias. Acacias in general do not meet the forage requirements for maintenance of sheep. Dry matter digestibility is often below $50 \%$ due to a high lignin content and consequently animals on high acacia diets have difficulty reaching their daily energy requirement, and the build up of indigestible lignin can cause compaction. The digestibility of protein is also low due to the binding action of tannins $[6,27]$.

Being a leguminous shrub however they do have the advantage of maintaining higher protein levels in their foliage as it matures than grasses and other herbage. Crude protein contents varying from 14 to $19 \%$ have been reported from a range of different provinces of $A$. saligna from south-western Australia [R. Ferdowsian, pers. comm.].

Their role as a protein supplement to standing dry feed has not been confirmed by grazing experiments but would appear to be confirmed by two cases from commercial experience [30: A.N. Buchanan, pers. comm.].

In the second case, 2300 Merino ewes were maintained for five months on 60 ha of A. saligna and inter-row grass plus an adjacent 20 ha of dry annual pasture. The three year old plantation consisted of trees directly seeded into rows $10 \mathrm{~m}$ apart and was subdivided into five 12 ha blocks. The inter-row space was sown to a mixture of perennial veldt grass (Erharta calycina var. "Mission"), love grass (Eragrostis curvula var. "Consol") and serradella (Ornithopus compressus).

Newly shorn sheep were rotated through these blocks in one mob spending four weeks in each block. The acacia feed was further rationed by cutting only sufficient for six to seven days at one time. This assured a continual supply of the full range of foliage available, from young to old phyllodes.

The edible dry matter of tree fodder and grass were estimated at 4.0 and 
2.0 tonnes per hectare, respectively. Sheep had constant access to the area of annual pasture (serradella and annual ryegrass) as this contained the only watering point. Feed available was estimated at 3 tonnes per hectare edible dry matter in January but there was no significant feed remaining in this area after two months.

The contribution of the acacia can be inferred from the fact that the estimated amount of grass and pasture would only be sufficient to maintain that number of adult sheep for about 90 days. In addition that feed would be very low in protein, probably around 4 to $5 \%$.

Recent work with $A$. aneura in Queensland suggests it may be possible to increase the digestibility of protein by introducing exotic rumen flora to sheep in a similar way that toxicity in leucaena was overcome. Drenching sheep with rumen fluid from feral goats produced an increase in nitrogen digestibility of $12 \%$ and an increase in intake of $17 \%$ in one study [27].

Economic value of acacia. Studies that monitor liveweight, wool growth and vegetation changes are required before the value of acacia can be assessed in comparison with alternatives. In the above example, the saving in grain feeding at $\$ 1$ per head per month is $\$ 11,500$ or $\$ 144$ per hectare of acacia plantation. In most years, the need for supplementary feeding would be only two to three months putting a value of $\$ 60$ to $\$ 90$ per hectare.

A distinct advantage of $A$. saligna is that it establishes readily from seed at a cost varying from $\$ 80$ to $\$ 150$ per hectare. A disadvantage of the feeding regime described above is the need for regular cutting. This was carried out by the farmer with a chainsaw, requiring six hours cutting per week. The current cost of mechanical pruning is $\$ 30$ to $\$ 60$ per hectare per year. $A$. saligna regrows vigorously when cut at 30 to $50 \mathrm{~cm}$ above ground level.

The expected life of a plantation under such management is unknown, although its survival in the wild is about 15 years.

Landscape value of acacia. The fact that Acacias establish relatively easily on a wide range of soils makes them a valuable addition to other species on degraded sites and other areas unprofitable under conventional agriculture.

On waterlogged and mildly saline sites, they can potentially increase draw down of saline watertables. On all sites they contribute protection from wind erosion and the ability to fix atmospheric nitrogen.

Acacia saligna is being used and studied as the basis for a system of wide spaced agroforestry on several farms where pasture or crop can be grown between the rows. In this case the forage value may be less important than the shelter effects of these rows, spaced 30 to $90 \mathrm{~m}$ apart (E.C. Lefroy, unpublished).

\subsection{Wet temperate zone}

This zone supports beef cattle and dairy cattle in addition to sheep for wool 
production. There are no large areas of fodder trees or shrubs in production although there are limited plantings of several species (see Table 3).

There is however increasing interest not only because of their ability to supply autumn feed but also because of the need to correct hydrological imbalance caused by the replacement of areas of native vegetation with annual pasture and crop.

The major disadvantage is the time necessary to protect trees from stock before they are productive. This is particularly so for the three species listed in Table 3 with edible fruit, which take 5 to 10 years to come into production. Yields of $100 \mathrm{~kg}$ per tree for mature honey locust and carob have been reported $[8,36]$ but there is no local data on animal response to these feeds to support their use.

Both the carob and the oak have been important in agroforestry systems of the mediterranean area providing forage as well as improvements in soil fertility and microclimate [15]. However, these systems have evolved over several hundred years and may not be relevant to the present economic and social structure of agriculture in Australia due to the labour intensive management required.

The willow and poplar species, however, can be managed as browse plants in much the same way as tagasaste and Acacia saligna [17]. Willows have been reported to have high protein and in vitro digestibility $(16.2 \%$ and $65.8 \%$, respectively) and to produce weight gains of $43 \mathrm{~g}$ per day in young sheep over a six week period as the sole feed [5].

Poplars such as Populus deltoides are used on a small scale in wide spaced agroforestry at densities of about 300 stems per hectare to provide timber and fodder from prunings [36].

\section{Conclusion}

The role of cultivated trees and shrubs as sources of fodder in Australia is that of supplying feed during periods of seasonal nutritional shortage. In northern Australia this period can last from April to October. In southern Australia it is generally from February to May.

Outside these periods, they can rarely compete with more abundant herbaceous feed due to their higher costs of establishment and management, their generally lower digestibility and the fact that they are often less accessible and acceptable to animals.

Only two species, Leucaena leucocephala and Chamaecytisus palmensis, have shown their ability to act as the sole source of feed for extended periods. The role of other species is in providing supplements of protein and other nutrients to dry pasture, and in the case of rangeland species, as the only source of nutrition during drought when all other feed is absent.

An important factor contributing to the commercial success of cultivated 
species is that they are easily and inexpensively established. The two species that have achieved commercial success are both leguminous shrubs that establish readily from seed.

A limitation with the present use of cultivated browse species is the dependence on stands of single species. The use of mixed species of trees and shrubs and the selection of complementary inter-row grass and herbaceous species would lessen the impact of insects and disease.

Management techniques developed to maximize production and persistence of cultivated browse plants involve short periods of intense grazing followed by long periods of recovery. Strategies similar to this may be necessary in the arid and semi-arid rangelands to retain palatable species that are now in decline.

\section{References}

1. Arieli A, Naim E, Benjamin RW and Pasternak D (1989). The effect of feeding saltbush and sodium chloride on energy metabolism in sheep. British Soc Anim Prod 49: 451457

2. Chippendale GM (1968). A study of the diet of cattle in central Australia as determined by rumen samples. Tech Bull No 1, Primary Industries Branch, Northern Territory Administration, Darwin

3. Corbet HA (1951) Fodder trees; suggestions for their wider use. Imperial printing company, Perth

4. Craig GF, Bell DT and Atkins CA (1991) Nutritional characteristics of selected species of Acacia growing in naturally saline areas of Western Australia. Aust J Exp Agric 31: $341-345$

5. Dann PR and Axelsen A (1986) Willow (Salix spp.) as drought feed for sheep. Proc Aust Soc Anim Prod 16: 408

6. Dann P and Low S (1988) Assessing the value of browse plants as alternative sources of fodder. Agricultural Science 1: 20-27

7. Dann P (1991) Fodder Trees in New South Wales. In: Proceedings, the Role of Trees in Sustainable Agriculture. Bureau of Rural Resources, Canberra

8. Esbenshade H and Wilson G (1986) Growing carobs in Australia. Goddard and Dobson, Melbourne

9. Everist SL (1969) The use of fodder trees and shrubs. Queensland Dept Primary Industry Advisory leaflet No 1024

10. Goodchild AV and McMeniman NP (1986) Nutritive value of Acacia foliage and pods for animal feeding. In: Turnbull JW, ed, Australian Acacias in Developing Countries. ACIAR, Canberra

11. Graetz RD (1986) A comparative study of sheep grazing a semi-arid saltbush pasture in two condition classes. Aust Rangel J 8(1): 46-50

12. Graetz RD and Wilson AD (1979). An assessment of herbivore diets in the chenopod shrublands. In: Graetz RD and Howes KMW, eds, Studies of the Australian Arid Zone. IV. Chenopod Shrublands, pp 144-159. CSIRO, Melbourne

13. Holm, AMcR (1986) The assessment of range trend in Western Australian pastoral shrublands. In: Rangelands: A Resource under Siege, Proc 2nd Inter Range Congr Adelaide

14. Imperial Agricultural Bureaux (1947) The use and misuse of shrubs and trees as fodder. Joint Publ 10, Imperial Agr Bureaux, Aberystwyth 
15. Joffre R, Vacher J, de los Llanos C and Long $\mathbf{G}$ (1988) The dehesa: an agrosilvopastoral system of the Mediterranean region with special reference to the Sierra Morena of Spain. Agroforestry Systems 6: 71-96

16. Jones RJ (1979) The value of Leucaena leucocephala as feed for ruminants in the tropics. World Anim Rev 31:13-23

17. Kraayenoord CWS and Hathaway RL (1986) Plant Materials Handbook for Soil Conservation. Soil conservation centre, Ministry of Works and Development, Wellington NZ

18. Le Houerou HN (1980) Browse in North Africa. In: Le Houerou HN, ed, Browse in Africa, pp 52-82. International livestock centre for Africa, Addis Ababa

19. Leigh $\mathrm{JH}$ and Mulham WE (1986) Selection of diet by sheep grazing semi-arid pastures on the riverine plain. Aust J Exp Agric Anim Sci 6: 468-474

20. Leigh $\mathrm{JH}$, Wilson $\mathrm{AD}$ and Williams $\mathrm{OB}$ (1970) An assessment of the value of three perennial chenopodiaceous shrubs for wool production of sheep grazing semi-arid pastures. Proc XI Int Grasslands Congress 55: 9

21. Malcolm CV, Clarke AJ, D'Antuono MF and Swann TC (1988) Effects of plant spacing and soil condition on the growth of five Atriplex species. Agric Ecosystems and Environ 21: $265-279$

22. Malcolm CV and Pol JE (1986) Grazing and management of saltland shrubs. J Dept Agric West Aust 27: 59-63

23. Malcolm CV, Swann TC and Ridings HT (1980) Niche-seeding for broadscale forage shrubs establishment on saline soils. Intern Sym on reclamation and management of salt affected soil, Karnal, India, Int Soc of Soil Sci 539-544

24. Marshall JK (1972) Principles of soil erosion and its prevention. In: Hall N, ed, The Use of Trees and Shrubs in the Dry Country of Australia. Aust Govt Pub Service, Canberra

25. Mattinson BC and Oldham CM (1989) Proc 16th Int Grasslands Congr Nice

26. McGowan AA (1991) The role of trees and shrubs as sources of fodder in Victoria. In: The Role of Trees in Sustainable Agriculture. Bureau of Rural Resources, Canberra

27. Miller S (1991) Improving the nutritional quality of mulga. The Mulga Line, Dept Primary Industries, Charleville, Qld

28. Mitchell AA and Wilcox DG (1988) Plants of the Arid Shrublands. University of Western Australia press with the Western Australia Dept of Agriculture

29. Morrissey JG and O'Connor REY (1988) Fair use and fair go; twenty-eight years of station management. Paper presented to the 5th Biennial Conference. Aust Rangeland Society, Longreach, Queensland

30. Nichols JE (1944) The behaviour of sheep browsing during drought in Western Australia. Proc British Soc Animal Prod, pp 66-73

31. Oldham CM, Allen G, Moore PM and Mattinson BC (1991) Animal Production from tagasaste. J West Aust Dept Agric Vol

32: 24-30 32. Pratchett D (1989) The prospects for leucaena on the Ord. J Dept Agric Western Australia 30: 2

33. Pratchett D (1991) Leucaena production on the Ord River Irrigation Area. Proc AMLRDC Shrub Legume Workshop, Brisbane

34. Purvis JR (1986) Nurture the land: my philosophies of pastoral management in central Australia. Aust Range J 8: 110-117

35. Quirk MF, Paton CJ and Bushell JJ (1990) Increasing the amount of leucaena on offer gives faster growth rates of grazing cattle in South East Queensland. Aust J Exp Agric 30: $51-4$

36. Reid R and Wilson G (1985) Agroforestry in Australia and New Zealand. Goddard and Dobson, Melbourne

37 Salerian JS, Malcolm CV and Pol JE (1987) The economics of saltland agronomy. Technical Report 56, Div Res Man, Western Australia Dept Agric

38. Snook LC (1986) Tagasaste. Nightowl Publishers, Shepparton, Vic, $102 \mathrm{pp}$

39. Standing Committee on Agriculture (1990) Feeding standards for Australian Livestock: ruminants. Ruminant sub-committee, Standing Comm on Agric, Canberra 
40. Stafford-Smith DM and Morton SR (1990) A framework for the ecology of arid Australia. J of Arid Environ 18: 255-278

41. Stringi L, Sarno R, Amato G, Leto G, Gristina L and Corrao A (1987) Shrub utilization in semi-arid environments: bio-agronomic aspects and their use in sheep husbandry. World Review of Animal Production XXIII (2): 79-90

42. Squires VR and Siebert BD (1983) Botanical and chemical components of the diet and liveweight change in cattle on semi-desert rangeland in Central Australia. Aust Rangel J 5 (1): $28-34$

43. Squires VR (1989) Australia: distribution, characteristics and utilization of shrublands In: McKell CM, ed, The Biology and Uitilization of Shrubs. Academic Press, N.Y.

44. Torres F (1983) The role of woody perennials in animal agroforestry. Agroforestry Systems 1: 131-163

45. Vercoe TK (1986) Fodder potential of selected Australian tree species. In: Turnbull JW, ed, Australian Acacias in Developing Countries, pp 95-100. ACIAR Proceedings No 16 ACIAR, Canberra

46. Warren BE, Bunny CJ and Bryant LB (1990) A preliminary examination of the nutritive value of four saltbush (Atriplex) species. Proc Aust Soc Anim Prod 18: 424-427

47. Watson IW and Holm AMcR (1990) The benefits of palatable shrubs for wool production in a semi-arid environment. Proc 6th Aust Range Conf Carnarvon

48. Wesley-Smith R (1991) The use of woody vegetation for fodder in the Northern Territory in The role of trees in sustainable agriculture. Bureau of Rural Resources, Canberra

49. Wheeler JL and Freer M (1987) In: Alexander and Williams, eds, Pasture and Forage: The Feed Base for Pastoral Industries, pp 164-182. The Pastoral Industries of Australia

50. Wilcox DG (1979) The contribution of the shrub component in arid pastures to the production from sheep. In: Graetz RD, ed, Studies of the Australian Arid Zone. IV, pp 170-177 Chenopod Shrublands. CSIRO, Melbourne

51. Wildin JH (1991) The role of trees as a source of fodder in Queensland. In: The Role of Trees in Sustainable Agriculture. Bureau of Rural Resources, Canberra

52. Wilson $\mathrm{AD}$ (1969) A review of browse in the nutrition of grazing animals. J Range Man 22: $23-28$

53. Wilson AD (1977) The digestibility and voluntary intake of the leaves of trees and shrubs by sheep and goats. Aust J Agric Res 28: 501-508

54. Wilson AD (1990) The effect of grazing on Australian ecosystems in Proc Ecol Soc Aust 16: $235-244$ 